\title{
PATRIARCAVIRUS, FEMINIST DYSTOPIAS AND COVID-19: REFLECTIONS ON THE PHENOMENON OF GENDER PANDEMICS
}

\section{PATRIARCAVIRUS, DISTOPÍAS FEMINISTAS Y COVID-19: REFLEXIONES SOBRE EL FENÓMENO DE PANDEMIA DE GÉNERO}

\section{Almudena MACHADO-JIMÉNEZ}

Author / Autora:

Almudena Machado-Jiménez

Universidad de Jaén

Jaén, Spain

amachado@ujaen.es

https://orcid.org/0000-0002-4792-6711

Submitted / Recibido: 14/03/2021

Accepted / Aceptado: 12/05/2021

To cite this article / Para citar este artículo: Almudena Machado-Jiménez, A. (2021).

Patriarcavirus, feminist dystopias and COVID-19: reflections on the phenomenon of gender pandemics. Feminismo/s, 38, 359-388. https://doi.org/10.14198/

fem.2021.38.14

Licence / Licencia:

This work is licensed under a Creative Commons Attribution 4.0 International.

\section{(c) (1)}

(c) Almudena Machado-Jiménez

\begin{abstract}
This essay examines contemporary feminist dystopias to study the phenomenon of gender pandemics. Gender pandemic narrative allegorises possible aftermaths of patriarcavirus, unleashing many natural disasters that force global biopolitics to hinder gender equality. The main objective of this essay is to explain how gender pandemics are appropriated in patriarchal utopian discourses as a pretext to control female empowerment, diagnosing women as diseased organisms that risk the state's well-being. Moreover, the novels explore the interdependence between biology and sociality, portraying the acute vulnerability of female bodies during and after the pandemic conflicts, inasmuch as patriarchal power arranges a hierarchical value system of living that reinforces gender discrimination. Particularly, the COVID-19 emergency is analysed as a gender pandemic: the exacerbated machismo and the growing distress in the female population prove that women are afflicted with a suffocating patriarcavirus, which has critically gagged them in the first year of the pandemic.
\end{abstract}


Keywords: Dystopian literature; Feminism; Gender Pandemic; Patriarchal utopia; COVID-19; Precariousness

\section{Resumen}

Este ensayo revisa la distopía feminista contemporánea para estudiar la pandemia de género. La narrativa de pandemias de género alegoriza el patriarcavirus y sus secuelas, desencadenando múltiples desastres naturales que torpedean la igualdad de género en la biopolítica global. Como principal objetivo analizaremos la apropiación de la pandemia en el discurso utópico patriarcal para frenar el empoderamiento femenino, que será patologizado como altamente peligroso para el bienestar del Estado. Las novelas exploran así la interdependencia entre biología y socialidad, a través de la vulnerabilidad del cuerpo femenino durante y después de conflictos pandémicos, ya que el patriarcado opera juicios de valor sobre la vida jerárquicamente, reforzando la discriminación por género. En particular, la emergencia de la COVID-19 se analiza como pandemia de género: el machismo exacerbado y la creciente ansiedad de la población femenina son prueba de un patriarcavirus sofocante que las ha amordazado gravemente en el primer año de pandemia.

Palabras clave: literatura distópica; feminismo; pandemia de género; utopía patriarcal; COVID-19; precariedad

\section{INTRODUCTION: PATRIARCAVIRUS AS THE PRIMAL DISEASE}

On 8 March 2020, several marches to celebrate International Women's Day denounced the systemic abuse perpetrated onto women sexually, workwise, in the household and the streets. Attendants to these demonstrations divulged the same topics of previous years - gender violence, the quest for equality and the feminist fight (Pando-Canteli \& Aurrekoetxea-Casaus, 2020) - though new metaphorical codes were used. The vehicle utilised in the rallies of 2020 represented patriarchy as a disease: Patriarcavirus. Having killed more women throughout history than the COVID-19 virus has ${ }^{1}$, this

1. The number of women's deaths worldwide due to the COVID-19 virus in 2020 was around 864,800 (Global Health 50/50, 2021). Small Arms Survey estimated that 66,000 women are killed intentionally every year (2012, p. 1), and the United Nations Office on Drugs and Crime informed that around 137 women are murdered every day by a member of their family (2019, p. 10). Particularly in 2017, there were 87,000 cases of female homicide, 50,000 of them executed by intimate partners. Considering these

Feminismo/s 38, July 2021, 359-388 
endemic social malady is pictured as more deadly and destructive to citizens' well-being and stability.

The increasing rumours of an unknown virus that deeply affected China's population and advanced to Europe with Italy's imminent lockdown endangered people's attendance at these street demonstrations, particularly in Spain -only 120,000 people participated in the street demonstrations of Madrid in 2020, whereas 2019 tripled the figures with 350,000 attendees (El País, 2020). Europe's demonstrators highly stressed the ground shared between patriarchy and coronavirus, comparing both agents as dangerous and infectious, though paying greater importance to the former, as it was already pandemic. In Spain, banners with the following titles manifest such analogy: 'El machismo ha matado a más mujeres en España que el coronavirus pero a nadie le importa', 'La verdadera epidemia es el patriarcado', 'El único virus peligroso es tu machismo', 'El verdadero virus es el patriarcado' or 'El patriarcado mata más que el coronavirus'. In France, the term patriarcavirus was highly quoted too, and the feminist collective FEMEN made a performance in Paris equating patriarchy with coronavirus. Dressed with protective clothing and equipped with fumigation dusters, they wrote on their bodies 'Stop a la pandemie patriarcale', 'Urgence vitale, virus patriarcale', or 'Eloignez vous! Patriarcavirus'. One year later, this street neologism has become viral and extensively used in the feminist cause in social networks, proving feminism is the antidote to stop patriarcavirus from spreading.

However, the harshness of COVID-19 could not be predicted, nor its consequences globally in the sanitary, economic, and social sphere. On 14 March, the Spanish government declared the state of emergency for two weeks, but the national lockdown would last more than two months and several curfews and restrictions followed. This situation entailed a national crisis that prompted the extreme right-wing supporters to revolt, asking for the government's resignation. Among their techniques to debunk the government, the reactionary blamed feminists - and the government as their ally — for spreading the virus as part of the leftist political agenda (Achtelik,

figures, the number of COVID-19 deaths would cover 15 years of the history of women killed by gender violence. 
2020; Mannering, 2020). Nonetheless, other events took place that same day, 8 March, and afterwards, which entailed a massification of groups without following any sanitary protocol: football matches, holy masses, and even a meeting of the extreme right-wing party VOX in the Vistalegre arena with thousands of people.

The vehement attack against the feminist movement as the primary source of contagion, together with the mobilisations by ultraconservative citizens during the COVID-19 lockdown, livened the latent political turmoil of an already decaying social organism. Gradually, the sanitary crisis was relegated, and COVID-19 grew as a trope to expose the underlying conditions of patriarcavirus by accentuating the existing social inequalities. This way, an analogy is established between the individual corporeal body and the socio-political body as infected organisms. Understanding disease as a «sickness that impairs or disrupts the normal functioning of the human body» (Blakemore \& Jennett, 2001), the COVID-19 health crisis augmented the impairment to reach gender equality in a society affected by patriarcavirus. The chronicity of such social disease's stigmata suggests the impossibility to recover, as Porta (2018) explains when defining chronic diseases.

The pathologisation of the female body on social and mass media for spreading the virus in the name of women's rights grants the consolidation of patriarchal ways of sociality based on male solidarity to dominate women (Hartmann, 2017, p. 219). In this process of whitewashing patriarchy as a healthy organism, parallelism has been established between femininity and illness, monstrosity, abnormality (Braidotti, 1994). By establishing such correlation, patriarchal leaders feel entitled to punish, control, and salve women from their natural condition to assimilate the patriarchal construct of salutary womanhood. As Braidotti concludes: «It is quite amazing how patriarchal conservatism always manages to recreate the optimal conditions for its survival by reasserting the priority of reproductive (non)sex over jouissance while submitting it to the imperatives of advanced capitalist societies» (1994, p. 42).

Patriarcavirus can be traced back to Classic philosophy or the first Abrahamic religions. The female body is depicted as defective, even as infectious, and consequently, as sinful and morally corrupt. God's acts exhibit his almightiness to administer the treatment onto women, patriarcavirus. 
Remarkably, the Old Testament presents numerous passages that portray women as infertile. Women like Sarai, Rebekah or Rachel and Leah are portrayed as sterile, and only after they show redemption to God, he bestows them the reproductive capacity: «When the Lord saw that Leah was unloved, he made her fruitful, while Rachel remained barren» (Gen 29:31). However, this pregnancy is deprived of any agency, as God utilises her body as a vessel, as the channel to maintain patrilineality: «I will bless [Sarai], and I will give you a son by her» (Gen 17:16; italics added).

The embodiment of healthy/infected subjects is gendered in patriarchal discourses because, by treating women as unhealthy, the expropriation of their generative capacity is justified to ensure the normative mechanism of power. Likewise, just as female corporeality is diagnosed as viral, all plagues and diseases have also been substantiated and narrated as feminine, constraining women to be the scapegoats of many human catastrophes. This parable originates gender pandemics.

\section{GENDER PANDEMICS, THE ORIGIN MYTH OF PATRIARCHAL UTOPIAS}

Gomel observes that the plague has been used as «one of the central tropes of biopolitics» (2000, p. 407), exploiting disease as a pretext to justify genocide. In the history of patriarchal utopias, plagues and pandemics served as a plea to acquit patriarchal abuses, incrementing the quotidian distress that the female utopian inhabitants usually experience. This violence/plague analogy is circumscribed by the previously mentioned parallelism of femininity and disease, utilising women solely as the bearers of damnation and, in opposition, installing male dominance as the salvation/solution to end with the plague. This dichotomy appears in some excerpts of the Bible, such as Sarai being blamed for some plagues in Egypt («The Lord struck Pharaoh and his household with severe plagues because of Abram's wife Sarai» [Gen 12:17]) or, more widely known, the passage of the whore of Babylon:

Fallen, fallen is Babylon the great. She has become a haunt for demons. She is a cage for every unclean spirit. [...] For all the nations have drunk the wine of her licentious passion. The kings of the earth had intercourse with her, and the merchants of the earth grew rich from her drive for luxury. [...] Depart from her, my people, so as not to take part in her sins and receive a 
share in her plagues, for her sins are piled up to the sky, and God remembers her crimes. [...] To the measure of her boasting and wantonness repay her in torment and grief; for she said to herself, 'I sit enthroned as queen; I am no widow, and I will never know grief.' Therefore, her plagues will come in one day, pestilence, grief, and famine; she will be consumed by fire. For mighty is the Lord God who judges her. The kings of the earth who had intercourse with her in their wantonness will weep and mourn over her when they see the smoke of her pyre. They will keep their distance for fear of the torment inflicted on her. (Rev 18:2-10)

The apocalypse itself is characterised as feminine to instil phallocentric ideological foundations from the Lord God to restore humanity from this chaos. Millenia later, this simile resonates nowadays in the mythification of COVID-19 as a new pandemonium where genetic-ethical issues are controlled. Particularly in patriarchal utopian narratives, natural disasters are employed strategically to recess in the quest for gender equality and prescribe patriarchal order. Several scholars (Braidotti, 1994, 2002; Grosz, 1994; Nast and Pile, 1998) stressed that biological bodies are circumscribed under specific geopolitics that prompt hierarchical relations. Particularly, Grosz remarks on how

Patriarchal oppression, in other words, justifies itself, at least in part, by connecting women much more closely than men to the body and, through this identification, restricting women's social and economic roles to (pseudo) biological terms. Relying on essentialism, naturalism and biologism, misogynist thought confines women to the biological requirements of reproduction on the assumption that because of particular biological, physiological, and endocrinological transformations, women are somehow more biological, more corporeal, and more natural than men. The coding of femininity with corporeality in effect leaves men free to inhabit what they (falsely) believe is a purely conceptual order while at the same time enabling them to satisfy their (sometimes disavowed) need for corporeal contact through their access to women's bodies and services. (1994, p. 14)

This interdependence between female corporeality and patriarchal biopolitics affects health's stability not only anatomically but also socially, considering that society is a collective organism. However, a healthy condition does not entail perfection in its well-functioning. According to the World Health Organisation, «health is a state of complete physical, mental and social well-being and not merely the absence of disease or infirmity». This 
description of a healthy organism echoes Moylan's critical utopia (1986), as patriarchal utopias aspire to be developed as a fully functioning political body without guaranteeing all their inhabitants' welfare, expressly women.

Similarly, I correlate the concept of health as a spectrum in the state of being with Cockburn's idea of the continuum of violence (2004). The variety of manifestations of sexual abuses and social oppression does not threaten the well-being of our contemporary patriarchal structures, as these ordinary stigmata attached to women tend to be overlooked, concealed, and even permitted in ruling institutions. And yet, when a malfunctioning of the social/biological system happens — as happens in times of social conflict or pandemic — , these overt dystopian realities are exposed and even magnified. These critical situations display the «reciprocal causality» (Goldstein, 2001, p. 129) between biology and culture ${ }^{2}$.

As if it were an inter-group armed conflict, the patriarchal belligerence in the management of pandemics locates an enemy on the Other, so that the mythification of new existential anxieties does not compromise the already hierarchical power relations. Gender pandemics choose women as the target adversary while skilfully construct a patriarchal utopia as the solution. Feminist dystopian narratives explore women's experiences before, during, and after the human disaster attending to the interdependence between biology and sociality. The authors warn the readership about the political manipulations conveyed by patriarchal governments to blame women's freedom for social and natural disasters and, consequently, to proceed with a purge process in which only customary womanhood can be considered healthy. In contrast, dissident members will be exposed to significant health risks in a hostile environment.

This is what Margaret Atwood imagined in her novel The Handmaid's Tale (1985). Atwood narrates how patriarcavirus gradually leads to a gender pandemic worldwide. The high levels of pollution - provoked by radioactive experiments and inorganic farming exploitation and industry- have directly affected the country's natality. The declension in birth rates, together

2. Goldstein's view on this two-directional causality does not intend to view biology under a reductionist lens, stating that biology is not destiny but actually diversity, and also how gender differences in aggression or empathy are not genetically inherent.

Feminismo/s 38, July 2021, 359-388 
with the demonstrations defending women's liberation, make radical conservative leaders blame women for this apocalyptic result:

Men highly placed in the regime were thus able to pick and choose among women who had demonstrated their reproductive fitness by having produced one or more healthy children, a desirable characteristic in an age of plummeting Caucasian birth rates, a phenomenon observable not only in Gilead but in most northern Caucasian societies of the time. The reasons for this decline are not altogether clear to us. Some of the failure to reproduce can undoubtedly be traced to the widespread availability of birth control of various kinds, including abortion, in the immediate pre-Gilead period. Some infertility, then, was willed, which may account for the differing statistics among Caucasians and non-Caucasians; but the rest was not. Need I remind you that this was the age of the R-strain syphilis and also of the infamous AIDS epidemic, which, once they spread to the population at large, eliminated many young sexually active people from the reproductive pool? Stillbirths, miscarriages, and genetic deformities were widespread and on the increase, and this trend has been linked to the various nuclear-plant accidents, shutdowns, and incidents of sabotage that characterised the period, as well as to leakages from chemical — and biological — warfare stockpiles and toxic-waste disposal sites, of which there were many thousands, both legal and illegal in some instances these materials were dumped into the sewage system and to the uncontrolled use of chemical insecticides, herbicides, and other sprays. (Atwood, 1985, p. 304)

The environmental disasters are intermingled with the feminist fights, portraying women's sexual liberation and freedom over their matrixial capacity as the solely responsible for the planet's decay. Out of this chaos, Gilead is founded; a patriarchal utopia is born. This theocratic phallocentric regime retreats to the Old Testament's passages to impose the biopolitical trope of femininity as a disease. Male leaders appropriate any women's reproductive rights to channel Gilead's restoration plan. Female corporeality is deprived of any agency during this gender pandemic; their freedom becomes a privilege in a world on the brink of extinction. Thus, patriarchal utopias execute a deceptive utilitarianism, inasmuch as women's sexual and reproductive exploitation during a gender pandemic is intended to grant all civilisation's well-being.

In the Red Center, Gilead's dissident women are informed of the two only alternatives for them based on their reproductive capacity: either serving

Feminismo/s 38, July 2021, 359-388 
as handmaids or working in the Colonies, where women are exposed to continuous toxic waste and the cleaning of hazardous territories ${ }^{3}$. Living in the Colonies is an announced death, but not because of the exposure to the gender pandemic in itself, but because of the precariousness and the apathy from the governments:

It's old women [...] and Handmaids who've screwed up their three chances, and incorrigibles like me. Discards, all of us. They're sterile, of course. [...] I'd say it's about a quarter men in the Colonies, too. Not all of those Gender Traitors end up on the Wall. (Atwood, 1985, pp. 260-261)

Atwood's narrative exposes how more women have struggled with the gender pandemic only after the government established solutions based on gender essentialism, e.g., greater mobility freedom for men, female isolation in the domestic space, the impossibility of group's mobilisations, austerity and chastity. Instead of acknowledging the mismanagement in environmental issues and the flaws of the capitalist socio-economic model, Gilead objectifies women's bodies to secure male liberties: greater mobility, sexual liberation, power in the public and private arena, the continuous establishment of aggressive laws.

In the latest decade, feminist dystopian narrative has widely used this trope, revealing how the environmental and social disasters of our contemporary neoliberal patriarchal civilisation can harness women through a discourse based on biological reductionism, jeopardising the advances of gender equality in pre-pandemic times. The imagery of gender pandemics in patriarchal utopias complicates the notion of gender as a construct independent from the constraints of sexual bodies. At the same time, it portrays the dangers of pursuing reductionist policies on women's biology with the pretext of granting national health security. Post-pandemic politics regard women as submissive vessels for humanity (or patriarchy)'s survival. In the sanitary administration of healthy corporealities, the patriarchal genetic-ethical views on gender see women's liberation and sexual empowerment as

3. Another option for dissidents contemplated in the narrative is to become sex workers, confined in a brothel as outlaws to satisfy those men's fantasies that are not appropriate in this Abrahamic patriarchal state. However, this option is not contemplated as an alternative for the handmaids in their indoctrination. 
dangerous. However, the authors of these contemporary patriarchal utopias portray the origins of gender pandemics differently.

Louise Katz's views of gender pandemic in The Orchid Nursery (2015) portrays the exploitation of an environmental crash by extremist patriarchal authorities to found a utopia. Mica, a compliant young woman of Perfect State, escapes from Civilisation to look for her friend Pearl, and it is only after she meets the Hag in the territory of the Unruly that she learns about the actual transition of the pre-pandemic world to the resulting patriarchal utopia:

Environmental ones. Tectonic. Also heat and cold and wind and water gone wild, my pet. And moral and cultural. Disasters, all. The natural and the man-made both. [...] the surface comforts we erected to protect ourselves from the elements in the world-the houses and dykes and sewers and such-snipper snap-all shredded in the end! And the niceties we constructed to save us from the demons in our brains-the reflex kindnesses and manners and social services and whatnot-chipper-chop-and no time to grow a decent scar! Things fall apart. But not all at once. The outer wrecked and the inner exposed by degrees. The inner where live the deepdeep fears, the ancient hatred. (Katz, 2015, p. 72)

However, the educational, religious and political institutions of an already existent and embellished patriarchy inform that the locus of this pandemonium is solely on women's behaviour:

Sheikh Humbum and Bishop Bozo of RUSA agree: «it's women's rudeness and disobedience that's to blame.» [...] I'd heard something similar at School from Mr Pule, who'd said that although God became very angry with all evildoers, he often became incredibly crass and disappointed with his daughters who had forgotten how to deport themselves properly and were resorting to wider and wilder ways, and could even endanger the mortal souls of their men because of their irresistibly amatory nature. (Katz, 2015, p. 115)

By selecting femininity as the pandemic's genesis, the subsequent patriarchal utopia of Perfect State is excused as the social cure to save humankind from extinction. Moreover, the manipulation of history underpins this theory and provides a biased version that perpetuates the binary oppositions between man/health and woman/disease. The resulting society continues overlooking natural disasters. Nevertheless, it instils extreme coercive restraints 
onto women to remain clean while satisfying male sexual needs (e.g., wearing dresslesses to guarantee available nakedness). If selected to attain for Perfection, girls are sent to the underground and transformed into orchidlike womanidols, whose limbs and teeth are amputated to leave their wombs awaiting fecundation:

The silken corsets are smooth over their waists and edged with flounces like vestigial ball-gowns to remind the Men of the Olden Days of moral pollution before the Liberation and Separation of Our Perfect state from the Agnostics, long may they burn. Above and below these broad bands their breasts and buttocks blossom out from the centre, unhampered by limbs, which are superfluous to (wo)Man's ultimate purpose. The simplicity of the Perfected forms allows no distraction from their function. (p. 20)

The impossibility of mobility in the mutilated bodies, together with their silence, grants the patriarchal leaders to consider healthy this new social organism, even though this well-being is attained by sacrificing women's rights to express dissidence.

The pandemic can be even imagined as a pretext to escape from contemporary feminist resistance in society and conceive a pure patriarchal community anew. This is the scenario that Jennie Melamed imagines in Gather the Daughters (2017), reflecting the paranoia of a patriarchal religious sect that escapes to an island to found the land of the ten original ancestors. The rottenness of their patriarchal moral standards with the coming of women's liberation is illustrated as an actual plague in the mainland: «the fire and pestilence that spread across the land were second only to the fire and pestilence of thought and deed hovering like a black smoke» (Melamed, 2017, p. 23). Social corruption is causal of the artificial pestilence in the wastelands. Likewise, the imposition of a righteous morality is equated to salvation from this disaster. And yet, the full responsibility to guarantee social welfare in this patriarchal utopia is onto women's corporeality, by being raped since birth by their fathers or husbands:

«When a daughter submits to her father's will, when a wife submits to her husband, when a woman is a helper to a man, we are worshipping the ancestors and their vision. [...] Only when these acts of submission are done with an open heart and willing mind,» the pastor continues, «only when this is done with a spirit of righteousness, can we reach true salvation». (pp. 24-25) 
The community's foundations bring back the old patriarchal religious trope of compulsory submissiveness to gain fertility and, consequently, society's security. Nevertheless, endogamy and continuous child abuse to indoctrinate girls into normative womanhood eventually aggravate the islanders' endemic ailments, significantly affecting women and their children. This gender pandemic also pathologises female rebellion, as the island's plague bursts when the daughters start a revolt against male adults after a whole life of suffering sexual abuse:

Why did such a terrible plague fall upon our society? Perhaps the ancestors asked God to punish us for our sins. [...] As I look upon us, I can see the reasons for their displeasure. We have strayed from them. We have strayed from their vision and their holiness. We clot up the minds of our daughters with useless knowledge instead of taking the precious time to teach them to be a solace to their fathers. Wives have forgotten how to support their husbands. [...] Men are swayed by the words of women, by the words of their wives and daughters who refuse to submit to their will as wives and daughters should. (p. 337)

Melamed, like other female writers on gender pandemics, observes how the patriarchal authorities show reluctance in working cooperatively to save the community, as mutual support and understanding eventually blur hierarchical power relations as well as binary oppositions. In patriarchal utopia, social health equates to the prosperity of privileged individuals, but it is with the coming of gender pandemics that the continuous abuses to women can eventually risk the phallocentric fantasy of well-being.

To prevent women from going astray either morally — with rebellionor biologically - with the natural decay of the body, O'Neill imagines a patriarchal utopia in which natural women are no longer existing. Instead, artificial eves created with Genetic Engineering can carry the burden of this patriarchal society. While Melamed imagines an austere scenario in the post-pandemic patriarchy, O'Neill's Only Ever Yours (2014) combines social networks' extreme surveillance, neoliberal over-sexualisation of female bodies and patriarchal fundamentalism. Also, Melamed's ancestors blamed women's conduct, but O'Neill feminist dystopia locates the genesis of the world's decay on biology itself: 
The infamous «girl Graves», thousands of unwanted daughters disposed of in an ever-expanding hole, their heads crushing against each other like broken china dolls. Drugstores with shelves upon shelves stacked with gender-specific fertility drugs, an easy to buy chewing gum. And the body learned. It learned that a female baby was an invader, come to steal her mother's beauty. A female baby was dangerous. (O'Neill, 2014, p. 49)

Daughters become invasive viral elements that interrupt and menace the patriarchy's fabricated organism. This pathologisation justifies female infanticide, eugenics and eves' disposability to enable the system's recovery to a healthy state. The construction of a healthy system repeats the patterns of patriarcavirus as an endemic disease that only harms women because of their biology, even if that biology is fabricated as it is the case of eves. Despite lacking any agency, these mechanical dolls have a conscience and, throughout the narrative, O'Neill hints at the distress and degradations that eves undergo to become the companions of the Inheritants of the Zones.

These resulting patriarchal utopias regulate gender pandemics by executing women after having fulfilled their commitment as incubators, i.e., when they become infertile. Female bodies' disposability minimises the risk of social infection by infertile/dissident subjects and maximises healthy/male authorities' supremacy. However, other authors like Meg Elison imagine an apocalyptic scenario of gender pandemics. In her novel The Book of the Unnamed Midwife (2014), the use of the «women's plague» serves as an allegory of the toxicity of patriarcavirus. This deadly fever primarily affects women and children worldwide, especially during childbirth, decimating the female population and leading humanity to the brink of extinction as a species. Unlike the other novels, the genesis of this gender pandemic is not arranged by patriarchal authorities, but it originated rather organically and randomly:

In the days when the world had not yet fallen, the screaming of sirens was constant. The structures that still held were designed to cope with emergency and disaster, but none of them could work indefinitely. Desperation moved block by block, and people fought and fled. They died of the plague, and they died of proximity to each other. [...]. Some people knew that would happen; they knew better than to open their doors when they heard cries of help. Others didn't. What disease cannot do, people accomplish with astonishing ease. (Elison, 2014, pp. 6-7) 
The unnamed midwife writes her testimonies during the apocalypse, recalling the pandemic's origins while working at the hospital. The lack of sanitary resources and the economic and social precariousness provoke the collapse of contemporary society. However, it is the ill-treatment of the few surviving women by heteronormative forces that provokes the endangerment of the human species. The scarcity of the female population converts the remaining living women into sexual luxuries to be commodified. If not killed by the fever, women die from conflict-related sexual violence, spending their last days being traded among male gangs to exchange food, medicines or guns, and continuously raped until death, either because of pregnancy or severe wounds:

When the slave traders found me, I figured I would die. They beat the shit out of me and raped me for days [...] I didn't know I was pregnant until I got here. [...] I don't care if none of the babies live. We don't deserve it, as a species. Evolution. (p. 274)

Elison illustrates how conditioned and vulnerable women are by their biological condition in pandemic times and equates this natural disaster to armed conflict instances. Indeed, the unnamed midwife resorts to cross-dressing and masculinisation to become able-bodied in this belligerent situation.

Patriarcavirus' resulting gender pandemic only aggravates the already existing rampant patriarchal brutality of pre-pandemic times. Her diary recalls episodes with victims of gender violence in the Emergency Room:

She looked pale, sick, hurt, and afraid [...]. She looked like prey, like a mark. She'd seen that look before on women who came to the ER, bleeding from one end or the other. Nobody chooses to be a victim, but after a lifetime of practice, it just happens. (p. 24)

Elison exposes the continuum of violence as an endemic chronic disease present in patriarchal civilisations. In apocalyptic times, women's empowerment is jeopardised by their perpetual representation of victimhood. However, the author does not indict the female individual, but instead criticises the complex and multiform character of systemic violence validated in contemporary society, which thwarts honest and complete empowerment of the feminine.

Many other female authors have appealed to the metaphors of patriarcavirus and gender pandemics to show women's experiences during disasters 
as vulnerable entities, embodied dissidence and subversive forces. Some examples of this narrative are Vox (2018), by Christina Dalcher; Bina Shak's Before She Sleeps (2018); The Water Cure (2018), by Sophie Mackintosh; Larissa Lai's The Tiger Flu (2018); or also Diane Cook's The New Wilderness (2020). Particularly, Lai remarks that myths «[do not] teach lessons in that moral way. What [they] can do is [they] can show us how to pay attention. [They] can show us the directions in which stories are moving and the directions that we might be moving» (Kang, 2020). The authors of these feminist dystopias utilise the myth of gender pandemics not merely as a cautionary tale but rather as near future representations of our patriarchal reality. This biopolitical trope helps understand the complex interdependence between environmental welfare, economic stability and social happiness. Gender pandemic stories encourage readers to think of alternative futures where social welfare does not depend on the exploitation of female corporeality. It dreams of more embracing forms of sociality based on mutual support - not only in fiction but also for our contemporary society.

\section{IS THE COVID-19 PANDEMIC A FEMINIST DYSTOPIA?}

When COVID-19 struck as a pandemic on 11 March 2020, several scholars addressed the social consequences this pandemic could have. Authors like Butler (2020) stated that this pandemic would serve as a great equaliser:

We could say that it treats us equally, puts us equally at risk of falling ill, losing someone close, living in a world of imminent threat. The virus operates within a global framework, but what about the rest of us? By the way it moves and strikes, the virus demonstrates that the global human community is equally precarious.

However, we have witnessed how the pandemic has reinforced the already existent social inequalities. Specifically, the mutability of patriarcavirus during this sanitary crisis has provoked a drawback in women's rights globally. Galindo addresses this quandary describing the pandemic as a tool to hide and downplay other social and political problems, like systematic racism, poverty, and machismo:

El coronavirus es un permiso de supresión de todas las libertades que a título de protección se extiende sin derecho a replica, ni cuestionamiento 
[...] El coronavirus es un instrumento que parece efectivo para borrar, minimizar, ocultar o poner entre paréntesis otros problemas sociales y políticos que veníamos conceptualizando. De pronto y por arte de magia desaparecen debajo la alfombra o detrás del gigante. (2020, p. 12)

In the last year, it has been manifested that COVID-19 was employed as a biopolitical strategy which, according to Preciado (2020), prompts to establish specific forms of understanding sociality and well-being: «Lo que estará en el centro del debate durante y después de esta crisis es cuáles serán las vidas que estaremos dispuestos a salvar y cuáles serán sacrificadas». This resolution relates to Lorenzini's politics of differential vulnerability, which arranges the value of citizens' lives hierarchically, eventually "producing and multiplying vulnerability as a means of governing people» (2021, p. 44). The infection of coronavirus has left the social organisms vulnerable to other maladies that were latent, worsening the gender breach during this natural disaster.

COVID-19 has become our contemporary gender pandemic, where women have experienced a setback to gender essentialist positions that force them to be more home-oriented and economically dependent. However, such social regression is not based on the fallacies of female disabledbodiedness during disaster/conflict or biological vulnerability, but rather on the effects of living the pandemic under a patriarchal civilisation. Several studies (Ahrenfeldt et al., 2021; Bwire, 2020; Jin et al., 2020; Kopel et al., 2020; Sharma et al., 2020) have expounded that men actually have higher mortality rates than women regardless of their age, and also hypothesised on possible effects on men's fertility, as SARS-CoV-2 binds with the ACE2's coronavirus receptors in testicles (Illiano et al., 2020). The reasons are still being under review, though it has been suggested that it can be due to genetic reasons and health and social habits like high-risk behaviours, e. $g$. smoking and drinking. Concretely, Bwire observes that «women have more responsible attitude toward the [COVID-19] pandemic than men. This may reversibly affect the undertaking of preventive measure such as frequent hand washing, wearing of face mask, and stay at home orders» (2020, p. 87). However, these preventive measures among the female population are related to the social construct of women's role of caregivers and because of a lack of mobility in the distribution of housework, being more in charge 
of 'feminine' traditional tasks, e.g., ironing or cleaning, inside the domestic space (Zamberlan et al., 2020).

Despite women being less vulnerable to the disease, the reduced physical activity, the pressure to bring healthy offspring, and the conciliation problems between work and childcare during the COVID-19 pandemic entailed more significant psychological distress — with stress, anxiety and depression - to women, and especially if they are pregnant (Davenport et al., 2020; Kopel, 2020; Liu et al., 2020). Liu et al. (2020) report that women have suffered higher Post-Traumatic Stress Symptoms than men after the COVID-19 outbreak in China. Kopel et al. explain how women are «treated aggressively if exposed to COVID-19 and remain a vulnerable risk group» (2020, p. 3) because of potential foetal distress, preterm delivery and fear of intrauterine viral transmission, although information is still lacking in this respect and further research is needed.

The ways of coping with the disease are manifested differently, and while women have been prone to anxiety and depression, men have manifested higher levels of learned helplessness (LH) and conspirational thinking, which intricately leads them to believe in conspiracy beliefs (Cassese et al., 2020). Cassese's definition of learned helplessness - a mechanism that «some individuals make when they perceive they have little or no control over aversive events» (pp. 4-5) - relates to Hernando's notion of the fallacy of individuality (2018), which sets the foundations of patriarchal civilisation. Hernando comments how patriarchal hierarchy underpins the fallacy of dependent individuality (usually attributed to men), while relational identities are exploited to bear this fantasy of the individual's self-sufficiency and control over the universe. The individual does not acknowledge his interdependence and vulnerability in the world, but he rather builds «un mundo a la medida de su capacidad de controlarlo, porque solo incluirá en él el conjunto de fenómenos que sea capaz de ordenar y por tanto de pensar organizadamente» (Hernando, 2018, p. 43). However, the COVID-19 pandemic has endangered this constructed reality, provoking a feeling of uncertainty in individuals, which occasionally leads to LH and the creation of conspiracy theories. Conspiracy theories aim to target and control the menacing power (an invisible microscopic virus) by creating myths which transform it into a noticeable entity that embodies the guilt, e.g., China, Trump's military, Bill

Feminismo/s 38, July 2021, 359-388 
Gates, the government, or feminists. Conspirational thinking provides a shield to prevent individuals from confronting the unknown and changing the established conventional constructs based on the fallacy of the individual. Moreover, it feeds society's binary arrangement into opposites by materialising the pandemic on an Other that becomes the scapegoat.

Mobility restrictions and socio-economic precariousness led to increased generalised pandemic anxiety, but this also has left structural sequels on the system. The COVID-19 crisis has endangered the sexual and reproductive health rights of many countries (Gausman \& Langer, 2020; Kopel et al., 2020) and has also affected the organisation of family household and workspaces, where women have undergone more changes and oppression. Women -especially those coming from lower social classes or racialised groups - have experienced more significant job loss if there were children or elders in the family household, as women were frequently assumed to be the family's childcarers (Fortier, 2020; Qian and Fuller, 2020).

Reichelt et al. (2021) argue that this greater job loss in the female population is causal of pre-pandemic irregularities in women's working conditions, e.g., having temporary or part-time jobs. Moreover, decisions such as teleworking or reducing working hours were more frequently taken among women, assuming traditional gender-roles attitudes. Particularly in Spain, Méndez-Giménez et al.'s study of depressive symptoms during confinement showcases that, from the $16.38 \%$ of their participants who suffer from depression, $78.2 \%$ were women. It is argued that this imbalance is due to relapse to conservative gender roles as mentioned above: «the confinement scenario could have caused a new imbalance between the roles of each other related to housework and childcare, which could have been a source of greater stress for women» (2021, p. 115).

Quian and Fuller (2020) and Fortier (2020) agree that state intervention must be accountable for supporting the care sector as an essential service, as well as resolving the gender wage gap. Only by solving structural inequalities in gender (and also race and class) can the institutions warrant collective well-being:

As long as it makes economic sense for women's paid labor, rather than men's, to decrease during economic crises like the one caused by the pandemic, it will be the case that women assume more of the unpaid caregiving 
duties, causing them to have reduced economic freedom and bargaining power, and thus reduced wellbeing [...]. The less that women are compelled to assume unpaid care work, the more they are free to participate in labor that accords with their desires, values, and interests. Governments' failures to enact legislative intervention that promotes gender equality needs to be seen not as respecting personal liberty, but as a choice to maintain a society that we know is actively repressive of and harmful to women. (Frontier, 2020, p. 84)

Apart from discrimination in the labour market and inequalities in unpaid care work, women have suffered from patriarcavirus in other forms during the pandemic: gender violence. Usher et al. (2020) warn that the effects of quarantine have increased the reports of domestic violence worldwide. The combination of social isolation, psychosocial stressors and precariousness, and coping addictions such as alcohol has prompted violent situations within the household that were invisibilised and, if not, could not be adequately attended to due to the sanitary crisis of COVID-19. The virus has even been weaponised, a characteristic recurrent in patriarchal mechanisms of power: «COVID-19 is used as a coercive control mechanism whereby perpetrators exert further control in an abusive relationship, specifically in the use of containment, fear, and threat of contagion as a mechanism of abuse» (p. 550). Bloem and Salemi (2020) remark that inter-group armed conflicts, like battles or bombings, diminished considerably in the first months of the pandemic, whereas violence against women and children (VAW/C), especially intimate-partner violence (IPV), almost doubled — notably in marginalised groups (Evans et al., 2020; Peterman et at., 2020). Peterman et al. (2020) alert that the global stats of IPV have risen acutely due to multiple reasons unleashed by the COVID-19 pandemic, though they stress that these figures were already alarming before, considering that more than one-third of the female population have suffered sexual abuse and more than one-third of the female homicides were committed by their intimate partners. Evans et al. refer to this phenomenon as «a pandemic within a pandemic» (2020, p. 2302). The collateral damages of the COVID-19 lockdown have obliged many women to live with their aggressors, and if not attacked by the virus, they were struck by the patriarchal pandemic.

Several public organisations have examined the effects of the COVID-19 pandemic on women, LGBTQ+, and racialised collectives' freedom and rights

Feminismo/s 38, July 2021, 359-388 
endangerment to bring awareness of their experiences and offer information about the gendered policy responses. In the policy report «How will the COVID-19 crisis affect existing gender divides in Europe?», the European Commission publishes a conclusive argument on the issue to understand how COVID-19 has become a gender pandemic:

Biologically women are not more at risk to COVID-19 than men are, while it seems that mwn $[s i c]$ are slightly more affected by the virus. However, women are risking to pay a higher price for the crisis than men. This can be in the form of a massive physical and mental workload during the crisis, that can lead to career disruptions both in the short and the long run, and in extreme cases even of physical sufferings. (Blaskó et al., 2020, p. 16)

The UN Women has included a specific dashboard called «COVID-19 and gender monitor», where information from multiple sources is collected and updated about the main concerns regarding women's rights. Besides, the organisation has published nine policy reports and more than 26 briefs, among which we can read how the effects of this pandemic on gender issues go from family-friendly advice to an urgency matter:

- «Family-friendly policies and other good workplace practices in the context of COVID-19: Key steps employers can take». (27 March 2020)

- «Impact of COVID-19 on violence against women and girls and service provision: UN women rapid assessment and findings». (27 May 2020)

- «COVID-19 and conflict: Advancing women's meaningful participation in ceasefires and peace processes». (3 August 2020)

- «Strengthening gender measures and data in the COVID-19 era: An urgent need for change». (4 March 2021)

This latest brief warns about how gender matters were already treated as a minor issue in most countries before the COVID-19 outbreak:

Prior to the pandemic, only 13 percent of countries had a dedicated budget for collecting and analysing gender data (primarily for health and reproductive health). Amidst the economic fallout from COVID-19, collecting and analysing gender data is likely to be pushed even further down the 
priority list, thus further exacerbating preexisting data gaps. (UN Women, 2021, p. 17)

This regression in research funds and data in gender matters leads the institution to claim that this is «not an 'equal opportunities' pandemic» (p. 19), and that intersectional approach to gender issues during and after the COVID-19 pandemic is an obligation and a right that we must not overlook.

Similarly, the World Health Organization published an advocacy brief titled «Gender and COVID-19» on 14 May 2020. The brief agrees with the UN's observation that the pandemic effects have been gender-based:

Pandemics and outbreaks have differential impacts on women and men. From the risk of exposure and biological susceptibility to the infection to the social and economic implications, individuals' experiences are likely to vary according to their biological and gender characteristics and their interaction with other social determinants. (World Health Organization, 2020, p. 1)

The report underpins the importance of conducting a gender analysis of the collected data of COVID-19's effects to elicit the most appropriate responses to this gender pandemic. Moreover, the organisation instils on member states to address this issue and guarantee access to sexual and reproductive health and rights despite the pandemic, which seems to be treated as a privilege during the pandemic moments. The inequity of health-care work is also addressed, as this field is where greater gender inequality is seen, not only in terms of precariousness (there is a lack of sanitary and psychosocial support to these workers) but quantitatively, as $70 \%$ of the global health workforce is carried out by women, $72 \%$ in Spain.

In collaboration with the Spanish Ministry of Equality, the organisation Instituto de la Mujer also published a report titled «La perspectiva de género, esencial en la respuesta a la COVID-19» in May 2020. In Spain, there is a significant disparity in the distribution of jobs related to caregiving, not only because of the previously mentioned imbalance in unpaid care work within the household but also because $84 \%$ of the sanitary staff are women. Besides, the cleaning and caregiving workers and domestic employees - a collective severely affected during the lockdown - must be added, whose majority is made of women, as well as other workers who have proved essential. Due to the high presence of women in the caregiving role, the institutions 
recommend giving women responsibilities in decision-making to ensure gender equality in the development of this sanitary and socio-economic crisis:

Los condicionantes de género determinan la diferencia del impacto de la crisis en mujeres y hombres. El rol tradicional de cuidadoras asignado a las mujeres les otorga un grado de presencia en la respuesta a la enfermedad que debe ser tenido en cuenta en el abordaje de la crisis. Ignorar el impacto de género en las consecuencias económicas y sociales agravará las desigualdades. Para evitarlo, las mujeres deben formar parte tanto de la respuesta directa como de la toma de decisiones, es decir no pueden ser solo quienes proporcionan salud global mientras los hombres lideran. (Instituto de la Mujer, 2020, p. 9)

However, out of the 3,548,312 citizens who suffered from unemployment in March 2020, 57\% were women. Besides, telephone reports to 016, the national hotline for gender-based violence, almost doubled in the first month of the lockdown, up to $48 \%$. Searches of the service's official web page augmented to $733.3 \%$, and psychological assistance via WhatsApp to $129.3 \%$ (p. 14). The disturbing figures of gender violence in Spain prompted the elaboration of a guide for the victims (and not the perpetrators), particularly of IPV, titled «Guía de actuación para mujeres que estén sufriendo violencia de género en situación de permanencia domiciliaria derivada del estado de alarma por COVID-19».

The data presented in this essay exposes that COVID-19 can be treated as a gender pandemic. It has deeply provoked an impact on all citizens worldwide, especially on women, who suffered overall more reduced mobility, conciliation problems, labour discrimination, and exacerbated violence in the gender axis -inequalities that were already existing in pre-pandemic times. Anita Bhatia, the deputy executive director of UN Women, warned that the problem of this pandemic onto women is not only in an increase of domestic violence but that it is causing

a fundamental rethinking about the role of women taking place in some societies, because women are now carrying such a huge burden of care and there is a risk that we may just slip back to the stereotypes of the 1950s when women were at home and men were outside. (Young, 2020). 
One year could risk 25 years to the development of women's rights and freedom. The criminalisation of feminism by political authorities and the media since the COVID-19 outbreak even favoured this setback to backward gender essentialism with the pretext of national security. The global political climate in the first year of the pandemic has been severely dramatic and conflictive, either because of the desperate cry for justice in discriminated groups - namely, BLM movements or Mexico's protests against rising feminicide- or because of fascist and insurrection marches, e.g., the assault on the capitol in the USA or Spain's neo-nazi rallies and VOX's hate speech. The near future looks bleak, considering the global uncertainty about the years to come regarding the pandemic crisis and the masses' violent agitation. The dystopias displayed in this essay are now read as ill omens that this contemporary gender pandemic could bring.

\section{CONCLUSIONS: A CRY FROM THE GAGGED}

After one year of living in the COVID-19 pandemic, it has been manifested how the disease never behaved randomly and indiscriminately. The virus has severely affected marginalised people from the lower classes or racialised groups and has turned leisure and free mobility a social privilege. The coronavirus has stretched the imparities between the oppressor and the oppressed, being the latter seriously exploited due to labour precarity, while the former grew richer and healthy. Our current situation of pandemic anxiety results from our ways of constructing society, not from the virus itself, as «el virus actúa a nuestra imagen y semejanza, no hace más que replicar, materializar, intensificar y extender a toda la población, las formas dominantes de gestión biopolítica y necropolítica que ya estaban trabajando sobre el territorio nacional y sus límites» (Preciado, 2020). COVID-19 subsequent upturns as a reflection of our social behaviour, based on nonchalance and lack of solidarity.

Likewise, the reigning mechanisms of our society were already analogue to a viral organism. Regarding the case of patriarcavirus, the object of study in this essay, the patriarchal system establishes a parasitic symbiosis (Paracer $\&$ Ahmadjian, 2000). Sustaining their fantasy of autonomy in the community's relational identities, the individual becomes a commensal in the social 
organism without acknowledging his dependence. The individual establishes a parasitoid relationship from which he takes benefits while slowly harming and destroying the host. Nevertheless, the wellness condition of this social organism worsens if another viral invasion strikes it. Gender pandemics attest that what leads to a state of emergency is the coinfection between the unknown virus and the existing critical social maladies. Patriarcavirus appears in moments of natural disasters as an opportunistic infection that superimposes onto the emerging disease, hindering the healing process.

This resistance to treatment will be analogous to the opposition to change the basis of patriarchal/parasitic commensalism into a relationship of mutualist symbiosis/cooperative interdependence. The feminist dystopias displayed in the present essay present such patriarchal resistance to cooperation in violent and reactionary ways, since «the power imbalance of gender relations in most (if not all) societies generates cultures of masculinity prone to violence. These gender relations [...] run through every field» (Cockburn, 2004, p. 44). These toxic masculinities are ironically reinforced by establishing patriarchal utopias as the solution to cure humanity. However, the beautification of patriarchal systemic violence as a healing process works as a patch concealing women's nightmarish reality. By relating these stories from the experience of the female subaltern, the authors uncover the infected wound and expose a dystopian scenario-women are gagged and trapped by the social and geographical insularity of this system to be exploited as incubators:

The flower (wo)Man now opens her mouth a fraction, as if to whisper... then she opens it wider [...]. From the throat there issues a gutural hiss. And now, all along the line of womanidols the sound spreads, each toothless hole joining in until the room resonates with the unholy sibilance of this mutilated choir, tiers of hothouse orchids silently screaming. (Katz, 2015, p. 21)

Gender pandemic narrative hints at the most brutal outcomes of an imminent prospect. Years ago, the accounts described could be interpreted as cautionary tales, but today, after a year of the COVID-19 pandemic outbreak, we read them as reflections of our present time. Feminist marches have been forbidden and condemned, and murals of feminist leaders have been censored, whereas events in which hate crimes and fascism are exalted are permitted, glorified as acts of patriotic defence. The social alarm enshrouds 
misogynistic brutality; women's house walls become their muzzle. As has been demonstrated in the present essay, the COVID-19 gender pandemic does not originate in possible biological limitations of women (for this assumption was debunked), but rather on the biological reductionism of patriarcavirus on gender roles. The acknowledgement of a healthy interdependence between corporeality and sociality, between the individual and the community, could suppose the end of body limitations as we cooperatively work for better futures. However, the differential vulnerability that prevails on the biopolitics of our contemporary society continues stigmatising the Other. We may recover from COVID-19 in the coming years, but we will have to work harder together to recover from the long-term damages of patriarcavirus - a socio-historical construct so chronic that it looks like it was an incurable congenital disease. The antidote is in feminism(s), in the voices of the gagged.

\section{REFERENCES}

Achtelik, K. (2020, June 26). Can feminists be blamed for Corona? HeinrichBöll-Stiftung. Gunda Werner Institute. www.gwi-boell.de/en/2020/06/02/ can-feminists-be-blamed-for-Corona

Ahrenfeldt, L. J., Otavova M., Christensen K., \& Lindahl-Jacobsen R. (2021). Sex and age differences in COVID-19 mortality in Europe. Wien Klin Wochenschr, 333, 393-398. https://doi.org/10.1007/s00508-020-01793-9

Atwood, M. (1985). The handmaid's tale. Houghton Mifflin Harcourt.

Blakemore, C., \& Jennett, S. (2001). Disease. The Oxford companion to the body. Oxford University Press. https://doi.org/10.1093/ acref/9780198524038.001.0001

Blaskó, Z., Papadimitriou, E., \& Manca, A. R. (2020). How will the COVID19 crisis affect existing gender divides in Europe. EU Science Hub: The European Commission's Science and Knowledge Service. Publications Office of the European Union. https://doi.org/10.2760/37511

Bloem, J. R., \& Salemi C. (2021). COVID-19 and conflict. World Development, 140, 1-9. https://doi.org/10.1016/j.worlddev.2020.105294

Braidotti, R. (1994). Nomadic subjects: Embodiment and sexual difference in contemporary feminist theory. Columbia University Press. 
Braidotti, R. (2002). Metamorphosis. Towards a materialist theory of becoming. Polity Press.

Butler, J. (2020, March 30). Capitalism has its limits. Verso Books. https://www. versobooks.com/blogs/4603-capitalism-has-its-limits

Bwire, G. M. (2020). Coronavirus: why men are more vulnerable to Covid-19 than women? SN Comprehensive Clinical Medicine, 2, 874-876. https://doi. org/10.1007/s42399-020-00341-w

Cassese, E. C., Farhart C. E., \& Miller J. M. (2020). Gender differences in COVID-19 conspiracy theory beliefs. Politics \& Gender, 16(4), 1009-1018. https://doi.org/10.1017/S1743923X20000409

Cockburn, C. (2004). The continuum of violence: a gender perspective on war and peace. In W. Giles \& J. Hyndman (Eds.), Sites of violence: Gender and conflict zones (pp. 24-44). University of California Press. https://doi.org/10.1525/ california/9780520230729.003.0002

Cohn, C. (2013). Women and wars: Towards a conceptual framework. In C. Cohn (Ed.), Women and wars (pp. 1-5). Polity Press.

Cook, D. (2020). The New Wilderness. Faber \& Faber.

Dalcher, C. (2018). Vox. Berkeley.

Davenport M. H., Meyer S., Meah V. L., Strynadka M. C., \& Khurana R. (2020). Moms are not ok: COVID-19 and maternal mental health. Frontiers in Global Women's Health, 1(1), 1-6. https://doi.org/10.3389/fgwh.2020.00001

El País. (2020, March 9). Día Internacional de la Mujer: Así te hemos contado las manifestaciones del 8 de marzo en directo. El País. https://elpais.com/ sociedad/dia-de-la-mujer/2020-03-08/dia-internacional-de-la-mujer-las-manifestaciones-del-8-de-marzo-en-directo.html

Elison, M. (2014). The book of the unnamed midwife. 47North.

Evans, M. L., Lindauer, M., \& Farrell, M. E. (2020). A pandemic within a pandemic: Intimate partner violence during Covid-19. The New England Journal of Medicine, 383(4), 2302-2304. https://doi.org/10.1056/NEJMp2024046

Fortier, N. (2020). COVID-19, gender inequality, and the responsibility of the state. International Journal of Wellbeing, 10(3), 77-93. https://doi.org/10.5502/ ijw.v10i3.1305

Galindo, M. (2020). Desobediencia, por tu culpa voy a sobrevivir. Sopa de Wuhan. Pensamiento contemporáneo en tiempos de pandemia (pp. 119-128). ASPO. 
Gausman, J., \& Langer A. (2020). Sex and gender disparities in the COVID-19 pandemic. Journal of Women's Health, 29(4), 465-466. https://doi.org/10.1089/ jwh.2020.8472

Global Health 50/50. (2021, April 27). The COVID-19 Sex-Disaggregated Data Tracker. Global Health 50/50. https://globalhealth5050.org/ the-sex-gender-and-covid-19-project/the-data-tracker/

Goldstein, J. S. (2001). War and gender. Cambridge University Press.

Gomel, E. (2000). The plague of utopias: Pestilence and the apocalyptic body. Twentieth-century Literature, 46(4), 406-433. https://doi.org/10.2307/827840 Grosz, E. (1994). Volatile bodies: Towards a corporeal feminism. Indiana University Press.

Hartmann, H. (2017). The unhappy marriage of Marxism and feminism: Towards a more progressive union. In C. R. McCann \& S-K. Kim (Eds.), Feminist Theory Reader: Local and Global Perspectives (pp. 214-228). Routledge.

Hernando, A. (2018). La fantasía de la individualidad. Sobre la construcción sociohistórica del sujeto moderno. Traficantes de sueños.

Illiano, E., Trama F., \& Costantini E. (2020). Could COVID-19 have an impact on male fertility? Andrologia, 52(6), 1-3. https://doi.org/10.1111/and.13654

Instituto de la Mujer (España). (2020). La perspectiva de género, esencial en la respuesta a la COVID-19. Instituto de la Mujer y para la Igualdad de Oportunidades. https://www.inmujer.gob.es/diseno/novedades/IMPACTO_ DE_GENERO_DEL_COVID_19_(uv).pdf

Jin, J-M., Bai, P., He, W., Wu, F., Liu X-F., Han D-M., Liu S., \& Yang J-K. (2020). Gender differences in patients with COVID-19: focus on severity and mortality. Frontiers in Public Health, 8 (152), 1-6. https://doi.org/10.3389/ fpubh.2020.00152

Kang,J. (2019, September 2). Conversation: Larissa Lai. Medium, Sine Theta Magazine. https://sinethetamag.medium.com/conversation-larissa-lai-73e0a19d7196 Katz, L. (2015). The orchid nursery. Lacuna.

Kopel, J., Perisetti, A., Roghani, A., Aziz, M., Gajendran, M., \& Gajendran, H. (2020). Racial and gender-based differences in COVID-19. Frontiers in Public Health, 8(418), 1-8. https://doi.org/10.3389/fpubh.2020.00418

Lai, L. (2018). The Tiger Flu. Arsenal Pulp Press.

Liu, N., Zhang, F., Wei, C., Jia, Y., Shang, Z., Sun, L., Wu, L., Sun, Z., Zhou, Y., Wang, Y., \& Liu, W. (2020). Prevalence and predictors of PTSS during 
COVID-19 outbreak in china hardest-hit areas: gender differences matter. Psychiatry Research, 287, 1-7. https://doi.org/10.1016/j.psychres.2020.112921 Lorenzini, D. (2021). Biopolitics in the time of Coronavirus. Critical Inquiry, 47(S2), S40-45. https://doi.org/10.1086/711432

Mackintosh, S. (2018). The Water Cure. Anchor.

Mannering, L. (2020, May 29). Spain's right wing sees Coronavirus crisis as opportunity. Foreign Policy. https://foreignpolicy.com/2020/05/29/spain-right-wing-coronavirus-crisis-opportunity-feminism-women-rights-protest-march-8m/

Melamed, J. (2017). Gather the daughters. Tinder Press.

Méndez-Giménez, A., Cecchini, J. A., Fernández-Río, J., \& Carriedo, A. (2021). Physical activity and prevention of depressive symptoms in the Spanish population during confinement due to COVID-19. Psicothema, 33(1), 111117. https://doi.org/10.7334/psicothema2020.294

Ministerio de Igualdad (España). Guía de actuación para mujeres que estén sufriendo violencia de género en situación de permanencia domiciliaria derivada del estado de alarma por COVID-19. Delegación del Gobierno contra la Violencia de Género. https://violenciagenero.igualdad.gob.es/informacionUtil/covid19/GuiaVictimasVGCovid19.pdf

Moylan, T. (1986). Demand the impossible: Science fiction and the utopian imagination. Methuen.

Nast, H. J., \& Pile, S. (1998). Introduction: MakingPlacesBodies. In H. J. Nast and S. Pile (Eds.), Places through the body (pp. 1-14). Routledge.

O'Neill, L. (2014). Only ever yours. Quercus.

Pando-Canteli, M. J., \& Aurrekoetxea-Casaus, M. (2020). Prácticas discursivas feministas: Análisis de los lemas de la manifestación del 8M en Bilbao. Feminismo/s, 36, 205-229. https://doi.org/10.14198/fem.2020.36.09

Paracer, S., \& Ahmadjian, V. (2000). Symbiosis: An introduction to biological associations. Oxford University Press.

Peterman, A., Potts, A., O'Donnell, M., Thompson, K., Shah, N., Oertelt-Pirigione, S., \& van Gelder, N. (2020, April 1). Pandemics and violence against women and children. Center for Global Development. https://www.cgdev.org/sites/ default/files/pandemics-and-vawg-april2.pdf

Porta, M. (2018). Chronic disease. In J. M. Last (Ed.), A dictionary of public health. Oxford University Press. https://doi.org/10.1093/ acref/9780191844386.001.0001 
Preciado, P. B. (2020, March 28). Aprendiendo del virus. El País, https://elpais. com/elpais/2020/03/27/opinion/1585316952_026489.html

Qian, Y., \& Fuller, S. (2020). COVID-19 and the gender employment gap among parents of young children. Canadian Public Policy, 46(S2), S89-S101. https:// doi.org/10.3138/cpp.2020-077

Reichelt M., Makovi, K., \& Sargsyan, A. (2021). The impact of COVID-19 on gender inequality in the labor market and gender-role attitudes. European Societies, 23, S228-S245. https://doi.org/10.1080/14616696.2020.1823010

Shak, B. (2018). Before She Sleeps. Delphinium.

Sharma, G., Volgman A. S., \& Michos, E. D. (2020). Sex differences in mortality from COVID-19 pandemic: Are men vulnerable and women protected? JACC: Case Reports, 2(9), 1407-1410. https://doi.org/10.1016/j.jaccas.2020.04.027

Small Arms Survey. (2012, February). Femicide: A global problem. Small Arms Survey Research Notes, 14. http://www.smallarmssurvey.org/fileadmin/docs/ H-Research_Notes/SAS-Research-Note-14.pdf

The New American Bible. (2002). The Holy See. http://www.vatican.va/archive/ ENG0839/_INDEX.HTM

United Nations Office on Drugs and Crime. (2019). Global study on homicide: Gender-related killing of women and girls. UNODC. https://www.unodc.org/ documents/data-and-analysis/gsh/Booklet_5.pdf

UN Women. (2020, May 27). Impact of COVID-19 on violence against women and girls and service provision: UN women rapid assessment and findings. UN Women Data Hub. https://data.unwomen.org/publications/impact-covid-19violence-against-women-and-girls-and-service-provision-un-women-rapid

UN Women. (2020, June 26). COVID-19 and gender monitor. UN Women Data Hub. https://data.unwomen.org/resources/covid-19-and-gender-monitor

UN Women. (2020). COVID-19 and conflict: Advancing women's meaning ful participation in ceasefires and peace processes. UN Women. https://www.unwomen.org/ en/digital-library/publications/2020/08/policy-brief-covid-19-and-conflict

UN Women. (2021). Strengthening gender measures and data in the COVID-19 era: An urgent need for change. UN Women. https:// www.unwomen.org/en/digital-library/publications/2021/03/ strengthening-gender-measures-and-data-in-the-covid-19-era

UN Women, UNICEF \& ILO. (2020). Family-friendly policies and other good workplace practices in the context of COVID-19: Key steps employers can take. UN Women. https://www.unwomen.org/en/digital-library/publications/2020/03/ 
family-friendly-policies-and-other-good-workplace-practices-in-the-context-of-covid-19

Usher, K., Bhullar, N., Durkin, J., Gyamfi N., \& Debra, J. (2020). Family violence and COVID-19: Increased vulnerability and reduced options for support. International Journal of Mental Health Nursing, 29, 549-552. https://doi. org/10.1111/inm.12735

World Health Organization. (n.d.). Constitution. World Health Organization. https://www.who.int/about/who-we-are/constitution

World Health Organization. (2020, May 14). Gender and COVID-19: Advocacy brief. IRIS World Health Organization. https://apps.who.int/iris/ handle/10665/332080

Young, A. (2020, April 17). Pandemic set to worsen gender inequalities, UN warns [video]. France 24. https://www.france24.com/en/20200417-5lpercent-pandemic-set-to-worsen-gender-inequalities-un-warns

Zamberlan, A., Gioachin F., \& Gritti, D. (2021). Work less, help out more? The persistence of gender inequality in housework and childcare during UK COVID-19. Research in Social Stratification and Mobility. Advance online publication. https://doi.org/10.1016/j.rssm.2021.100583 